\title{
ALTERNATIVNÍ POHLED NA TEORII PENĚZ A MONETÁRNÍ POLITIKU
}

\section{Josef Klement}

\section{Chytil, Zdeněk a kol.: Eseje z postkeynesovské ekonomie}

Praha: Vysoká škola ekonomická v Praze, Nakladatelství Oeconomica, 2016. 183 stran. ISBN 978-80-245-2122-0.

Jak funguje soudobý bankovní systém a může centrální banka vůbec ovlivnit jeho fungování? Mají centrální banky kontrolu nad peněžní zásobou? Mohou trhy dosahovat rovnováhy a můžeme pomocí monetární či hospodářské politiky tlumit negativní projevy hospodářského cyklu? A konečně, můžeme po poslední krizi stále věřit v postuláty ekonomie hlavního proudu, nebo je na čase hledat odpovědi jinde, tedy hovořit o nutnosti změn v paradigmatu hospodářské a monetární politiky? Tyto a mnohé další klíčové otázky ekonomie ožívají v monografii Eseje z postkeynesovské ekonomie od autorského kolektivu pod vedením Zdeňka Chytila (dalšími autory jsou Lukáš Máslo a Martin Janíčko). Monografie nabízí českému čtenáři nejen obsáhlý přehled především monetárních konceptů postkeynesovských autorů, ale i vlastní pohled autorů v dosud nejrozsáhlejším materiálu vydaném v českém jazyce věnovaném této heterodoxní ekonomické škole.

Jak je patrné již z názvu knihy, nejedná se o jednolitý text, ale o soubor šesti esejí, které jsou metodologicky a obsahově do určité míry provázány. Obsahem esejí jsou témata: endogenní teorie peněz; pojetí úlohy centrální banky a fungování komerčních bank; fundamentální nejistota a ergodicita; fundamentální nejistota a centrální rovnováha; postkeynesovská teorie úrokové míry; finanční inovace a hospodářské výkyvy.

Pojícím prvkem celé publikace je kromě přiblížení známých i méně známých postkeynesovských ekonomických teorií především kritická analýza předkládaných konceptů, formulace vlastních pohledů a také jejich praktická aplikace na hospodářskou politiku. Mimo zájem autorů nezůstávají ani nejaktuálnější problémy současné (především) pak monetární ekonomie. Dozvíme se, proč neznamená fenomén záporné úrokové míry pro postkeynesovce žádný problém nebo proč se politika kvantitativního uvolňování může minout účinkem.

V jednotlivých částech monografie lze identifikovat pro čtenáře poněkud rozdílnou úroveň ,„čitelnosti“ či komfortu srozumitelnosti jednotlivých esejí. Zatímco první, druhá, pátá a šestá kapitola jsou čtenářsky velmi př́znivé, třetí a čtvrtá kapitola věnovaná metodologickým otázkám vyžaduje od čtenáře poměrně značné soustředění a často i potřebu nahlédnout do další literatury. Přesto tyto metodologické pasáže tvoří významná východiska pro analýzu a závěry v dalších částech monografie a čtenář se jimi musí ,prokousat“. Z hlediska logiky výkladu i metodologického přístupu jsem toho názoru, že se hlavní

* Josef Klement (josef.klement@vse.cz), Vysoká škola ekonomická, Národohospodářská fakulta. 
autor měl zamyslet lépe nad koncipováním pořadí kapitol. Bylo by určitě vhodnější, pokud by kapitola Fundamentální nejistota a centrální rovnováha byla zařazena jako kapitola třetí a teprve po ní by byla uvedena kapitola Kritika Davidsonova ,základního článku neoklasické víry": perspektiva prvotní príčiny.

První část úvodní eseje supluje pomyslný úvod do postkeynesovské ekonomie. Čtenáři nabízí popis fundamentálních pilíruo postkeynesovské ekonomie, jako je odmítnutí „vnitřní stability systému vyspělého tržního hospodářství s vlastními autoregulačními mechanismy“ (str. 14), neschopnost ,tržního mechanismu eliminovat cyklický vývoj hospodářství nebo zajistit stabilní tempo růstu při využití potenciálních zdrojů“ (str. 14), s tím spojená nedostatečná koupěschopná poptávka a dále pak důraz na fundamentální nejistotu spojenou s budoucím vývojem ekonomiky. Tyto až marxistické základy postkeynesovské ekonomie jen složitě obstojí před historickou zkušeností ekonomů i široké veřejnosti České republiky. Stoupenec liberálních pohledů by se však neměl nechat odradit, kniha rozhodně není pouhým soupisem dirigistických názorů.

Ve druhé části první eseje jsou otevřena nejdůležitější témata celé monografie. Velmi srozumitelnou formou jsou představeny čtyři koncepty teorie endogenních peněz, které se v postkeynesovské ekonomii koncipovaly. Jejich průnik lze spatřit ve společném přesvědčení, že peněžní nabídka je zásadním způsobem determinována poptávkou po nových penězích. Peníze v ekonomice vznikají endogenně jako výsledek poptávky domácností, podnikatelského sektoru a nebankovních finančních institucí po úvěrech od komerčních bank (str. 40).

Explanace teorie endogenní nabídky peněz je kladena do kontrastu výkladem neoklasického a monetaristického konceptu chápající peněžní zásobu jako exogenně stanovenou veličinu centrální bankou. Ekonomie hlavního proudu exogenitu v podstatě přebírá, kauzalita jde od depozit k tvorbě úvěrů (z monetární báze vzniká peněžním multiplikátorem peněžní zásoba). Teorie endogenní tvorby nabídky peněz kauzalitu zcela obrací. Kauzalita směřuje od peněžní zásoby k monetární bázi, peněžní zásoba je tudíž endogenní proměnnou. Firmy financují produkci dříve, než jsou vytvořeny úspory. Banky nejdříve poskytují úvěry a teprve následně hledají způsoby vyrovnání bilance na straně pasiv. „Za zmínku stojí i řízení pasiv komerčních bank, umožňující zvýšit jejich úvěrovou kapacitu zapůjčením fondů, které se v rozvaze objeví na straně pasiv - zmíněných státních dluhopisů, aniž by se pro vyrovnání bilance musely vzdát likvidních aktiv. Správa pasiv vnutila komerčním bankám roli agresivního ekonomického agenta, který hledá zákazníky, jejichž úvěr se v bilanci komerčních bank objeví na straně aktiv a teprve následně tomu přizpůsobuje svá pasiva.“ (str. 27). Nabídka peněz je výsledkem úvěrové kreace, kterou komerční banky poskytují v procesu poskytování úvěrů - přidělování úvěrů (credit rationing). Endogenitu navíc prohlubují nebankovní poskytovatelé půjček (např́iklad samotné firmy) a dále pak i finanční inovace. V závěru eseje autor inkorporuje uvedená teoretická východiska do praktické hospodářské politiky.

Druhá esej úzce navazuje na předchozí teorii a zabývá se fungováním centrální banky a komerčních bank z postkeynesovského pohledu, založeného na metodologii kritického realismu. Oproti metodologii hlavního proudu, vycházející z metodologie 
pozitivní ekonomie M. Friedmana, nestojí postkeynesovský kritický realismus na co nejpřesnějších predikcích, ale na snaze co nejlépe zachytit a vysvětlit nejdůležitější procesy v reálné ekonomice. Právě v době turbulencí a nepředpokládaného mikroekonomického i makroekonomického vývoje, kdy tradiční modely se svými predikcemi selhávají, mohou prístupy formulované na principech kritického realismu být pro hospodářsko-politické autority př́nosné.

Centrální banky nemají při řízení peněžní zásoby takovou moc, jakou jí přisuzují stoupenci hlavního proudu. „V krátkém období je centrální banka v zajetí trhu, který určuje její aktivity, zatímco v delším období jsou její možnosti silně eliminovány vznikem finančních inovací“ (str. 53). To je důvod, proč „centrální banky ve vyspělých zemích implicitně ve svých praktických opatřeních přistupují na pozice postkeynesovství“ (str. 51). Centrální banky stále využívají měnověpolitický režim cílování inflace - ten však za postkeynesovský označit nelze. Koncept cílování inflace nese silné prvky hybridity. Jeho teoretickým základem je nový konsensus. Ten sice uznává endogenní povahu nabídky peněz (absentuje však u něj ucelená teorie endogenních peněz) a exogenní tvorbu úrokové míry. Ta však obsahuje wicksellovské kořeny úrokové míry transponované do friedmanovského monetarismu (přirozená míra nezaměstnanosti). A zde se dle autorů dostáváme do protikladu i se samostatností centrální banky. Na jedné straně cílování inflace jako inovovaná tradiční keynesovská monetární politika, spojená s omezenou samostatností centrálních bank, a na druhé straně friedmanovský monetarismus jako zdroj přetrvávající koncepce nezávislosti centrálních bank.

Oproti předcházejícím prakticky laděným esejím se třetí kapitola zabývá vysoce abstraktní až filozofickou látkou. Autoři zde navazují na významné postkeynesovské autory (Davidson, O’Donnell či Setterfield) v hledání povahy a důvodu existence fundamentální nejistoty. Proč nedokážeme odhadnout úrokovou míru? Je důvodem nejistá povaha samotného světa kolem nás (ontologie), nebo naše nedostatečná schopnost poznání tohoto světa (epistemologie)? Autoři na rozdíl od Davidsona vnímajícího fundamentální nejistotu jako ontologický jev, považují fundamentální nejistotu za jev epistemologický.

Dalším důležitým námětem eseje byla samotná kritika „základního článku neoklasické víry“ dle Davidsona, který „,neoklasické ekonomii jakožto celku připisuje hledání konstant a časově invariantních struktur na způsob ,gravitačních konstant ““ (str. 77). Je zde uvedena kritika Álvareze a Ehntse, podle nichž se Davidson při své definici „základního článku neoklasické víry“ dopustil desinterpretace Samuelsonových výroků. Autoři docházejí k závěru, že ke zpochybňování platnosti klasické dichotomie (oddělenost nominálních a reálných veličin) a zároveň při přijetí konceptu kruciálních rozhodnutí a endogenních šoků (str. 78) i v plně deterministickém systému, ve kterém je vše endogenizováno, bude existovat jedna konstanta - systém samotný (alternativně „ultimátní vzorec“). Fundamentální nejistota by byla odstraněna až poznáním tohoto „ultimátního vzorce“.

Čtvrtá esej aplikuje princip fundamentální nejistoty na hledání makroekonomického ekvilibria. Autoři dospívají pomocí analýzy dvou variant vlastního centrálně rovnovážného modelu neúplné zaměstnanosti (s vyrovnávacím mechanismem přirozené úrokové míry a důchodovým vyrovnávacím mechanismem) $\mathrm{k}$ následujícím závěrům. Porušení 
předpokladu intertemporální uzavřenosti systému znamená, že určitá část úspor zůstane dlouhodobě neutracena. Existují dva kanály fundamentální nejistoty - kapitálový (subjektivně vnímané riziko z podnikatelského selhání) a likvidní (subjektivně pocitované riziko v řízení hotovostních toků). Ekonomika oscilující kolem centrální rovnováhy se s prohlubováním fundamentální nejistoty dostává dál a dál od rovnováhy. Snížení fundamentální nejistoty lze učinit dvěma zpo̊soby: 1) dodáním likvidity (to funguje do určitého bodu); 2) zvýšením státních výdajů (čímž se nahrazuje část poptávky za neutracené úspory). Ve finále by výše navržené snížení fundamentální nejistoty mělo posunout ekonomiku zpátky do rovnováhy. $\mathrm{S}$ tím budou zastánci hesla laissez-faire jen těžko souhlasit. Jestliže existuje centrální rovnováha, pak přece musí odpovídat situaci před státními zásahy a dodáváním likvidity - tedy s efektivním využíváním zdrojů pomocí tržního mechanismu. Pokud se několik politiků či úředníků centrální banky rozhodne zvýšit míru zásahů, pak jistě dojde k dočasnému boomu (a snížení míry nezaměstnanosti), nicméně ekonomika se logicky nenavrátí na původní trajektorii, respektive stejnou úroveň rovnováhy.

Rozdíly ve vnímání úrokové míry z pohledu nového konsensu a postkeynesovství a $\mathrm{z}$ nich plynoucí rozdílné postoje $\mathrm{k}$ aktuální měnověpolitické situaci přináší pátá esej. Zatímco monetární teorie nového konsensu (a tedy cílování inflace) je postavena na existenci Wicksellovy dvojí úrokové míry (přirozená a nominální), sám Keynes i postkeynesovci ji odmítají. Autoři rozlišují dva hlavní přístupy postkeynesovské monetární teorie (aktivistický př́stup a „,parking-it“ př́stup) a uvádějí jejich společné i odlišné atributy. Dle aktivistického př́stupu má centrální banka stanovovat úrokovou míru na úrovni inflace minimalizující míru nezaměstnanosti. Jaká by však měla být inflace minimalizující míru nezaměstnanosti, a co když se tento vysoce agregovaný ukazatel v čase mění? Na druhé straně zastánci „parking-it“ přístupu cílují růst produktivity práce. V zájmu zachování důchodové redistribuční neutrality by pak růst produktivity (v \%) měl odpovídat reálné úrokové míře (v \%), jak autoři dokazují v eseji. Do jaké míry však můžeme tuto úrokovou míru nazývat „férovou“, když růst produktivity jednotlivých agentů se může vzájemně značně lišit (nehledě na způsob samotného výpočtu produktivity), zůstává otázkou. Druhá část páté eseje již řeší nejaktuálnější palčivé problémy současné monetární politiky - zápornou úrokovou míru nebo např́klad politiku kvantitativního uvolňování. A nutno dodat, že tato pasáž je čtenářsky velmi zajímavá.

Poslední, šestá esej jako by úžeji navazovala na první dvě kapitoly, a to nejen tématem finančních inovací, ale i stylem. Autor nejdříve představuje vývoj a současný stav finančních inovací, a to nejen z pozice postkeynesovců, ale i francouzské školy regulace a částečně i ekonomie hlavního proudu. Malé mikroekonomické zefektivnění, způsobené finančními inovacemi, je převáženo negativem ve formě snížené makroekonomické stability. Jako příklad uvádí poslední finanční a hospodářskou krizi s dovětkem, že po jejím propuknutí ,,většina ekonomů hlavního proudu byla nucena [...] obrátit argumentaci téměř o příslovečných $180^{\circ}$ “ (str. 152). Zajímavé je, že autor v poznámce pod čarou (str. 151) uvádí, že také řada zástupců rakouské školy předvídala bublinu na trhu nemovitostí. 
Závěrem se doporučuje, aby regulační autority v oblasti finančních trhů vnímaly finanční stabilitu více jako veřejný statek a implementovaly intenzivnějšś a sofistikovanější regulace finančních trhů. Nicméně druhým dechem dodává, že „finanční sektor je sektorem velice kreativním a produktivním, pokud jde o jeho inovativní činnost, a proto má před regulačními autoritami ,předstih“ ex definitione“ (str. 153). S tím nelze než souhlasit. Ale vyvstává otázka: do jaké míry zajistí další regulace finančních trhů ochranu veřejného statku a nejde spíše o výsledek tlaku samotného finančního sektoru jako příklad zajetí regulátora.

Obě úvodní eseje a dále pátá a šestá esej jsou psány i přes svou nespornou fundovanost čtenářsky velmi př́stupnou formou. Proto nenajdou ocenění pouze u odborné veřejnosti, ale především mohou oslovit také studenty ekonomie vyšších ročníků. Vysoce abstraktní třetí a čtvrtá esej cílí svou náročností spíše na opravdové přívržence postkeynesovské ekonomie a $\mathrm{v}$ tomto pohledu je potřeba $\mathrm{k}$ nim přistupovat.

Monografie otevírá zajímavá a často až kontroverzní témata ekonomie a současné hospodářské politiky. Postkeynesovství nejenže odmítá značnou část teoretických základů ekonomie posledních 200 let a nabízí alternativní vysvětlení nejrůznějších jevů, jako je např́klad teorie endogenních peněz, ale především propaguje pro vyřešení identifikovaných ekonomických problémů přímé státní zásahy. Pro liberální ekonomy zastávající princip „laissez faire“ nemohou být taková řešení přijatelná, a proto by se mohlo zdát, že ani Eseje z postkeynesovské ekonomie nenajdou v jejich knihovnách místo. Avšak monografie není pouhým nekritickým souhrnem postkeynesovských teorií. V jednotlivých esejích se autoři k některým postkeynesovských konceptům vyslovují i kriticky. Za př́nosné lze považovat rovněž praktické aplikace a závěry pro hospodářskou politiku, stejně tak i závěrečné poznámky na konci kapitol. Zde autoři nejen sumarizují, ale rovněž formulují své vlastní pohledy. Navíc je to často právě pochopení opačných postojủ, které čtenáři umožňuje rozšiřit své obzory a fundovaně protiargumentovat. Proto bych knihu doporučil nejen zastáncům tohoto heterodoxního směru ekonomie, ale každému, koho zajímá ekonomie jako taková. 